\title{
Studi Sebaran Sedimen Dasar di Perairan Sungai Banjir Kanal Timur Semarang, Jawa Tengah
}

\author{
Nanda Rahmadi*, Sugeng Widada, Jarot Marwoto, Warsito Atmodjo, dan Rikha Widiaratih \\ Departemen Oseanografi, Fakultas Perikanan dan Ilmu Kelautan, Universitas Diponegoro \\ Jl. Prof. H. Soedarto, SH, Tembalang, Semarang. 50275 \\ Email:*nanda04.rahmadi@gmail.com
}

\begin{abstract}
Abstrak
Banjir Kanal Timur merupakan gabungan Tambak Lorok (Kali Banger) dan Kali Tenggang. Adapun sungai Banjir Kanal Timur melintasi kota Semarang bagian timur yang padat pemukiman dan industri. Banyak aktivitas manusia dan industri di sekitar daerah aliran sungai (DAS) ini. antara lain adalah industri tekstil, bahan makanan, bahkan terdapat tempat pelelangan ikan. Banyaknya aktiviitas manusia di sekitar wilayah sungai ini menimbulkan berbagai permasalahan lingkungan seperti penurunan kualitas air dan peningkatan proses sedimentasi pada mulut muara merupakan permasalahan yang ditimbulkan. Proses sedimentasi di muara sungai yang terjadi terus menerus akan menyebabkan pendangkalan dan sulitnya akses untuk menuju ke laut lepas. Tujuan dari penelitian ini adalah untuk mengetahui jenis sedimen dasar di Perairan Banjir kanal Timur dan melihat pola arus yang mempengaruhi. Sedimen dasar diambil secara langsung juga melaukan pengukuran batimetri. Terdapat 10 stasiun yang menjadi daerah penelitian dimana 2 stasiun berada di Muara Sungai Banjir Kanal Timur, dan lainnya berada di perairan yang lebih dalam. Hasil pengolahan data menunjukkan bahwa jenis sedimen yang berada di Muara Sungai Banjir Kanal Timur adalah lanau dan daerah yang lebih dalam mengandung pasir. Pola arus pada Perairan Banjir Kanal Timur merupakan arus pasang surut.
\end{abstract}

Kata Kunci : Banjir Kanal Timur, sedimen, arus

\begin{abstract}
The Banjir Kanal Timur is a combination of Tambak Lorok (Kali Banger) and Kali Tenggang. Meanwhile, the Banjir Kanal Timur river crosses the eastern part of Semarang, which is densely populated with industrial and residential areas. There are many human and industrial activities around this watershed (DAS). among others, the textile industry, foodstuffs, and there is even a fish auction. The large number of human activities around this river area has caused various environmental problems such as a decrease in water quality and an increase in the sedimentation process at the mouth of the estuary. The continuous sedimentation process in the river mouth will cause silting and difficult access to the high seas. The purpose of this study was to determine the type of bottom sediment in the East Canal Flood waters and to see the influencing flow patterns. Baseline sediments are collected directly as well as by bathymetry measurements. There are 10 stations which are the research areas, 2 of which are in the Muara Sungai Banjir Kanal Timur, and the others are in deeper waters. The results of data processing indicate that the type of sediment in the Banjir Kanal Timur River Estuary is silt and the deeper areas contain sand. The current pattern in the Banjir Kanal Timur is tidal flow.
\end{abstract}

Keywords: Banjir Kanal Timur, sediment, current

\section{PENDAHULUAN}

Wilayah Semarang dilalui oleh beberapa aliran sungai (DAS) seperti DAS Cilandak, DAS Garang, DAS Siangker, DAS Banjir Kanal Timur, DAS Sringin dan DAS Banjir Kanal Barat (Bapedalda, 2010). Banjir Kanal Timur mrtupakan gabungan Tambak Lorok (Kali Banger) dan Kali Tenggang. Adapun sungai Banjir Kanal Timur melintasi kota Semarang bagian timur yang padat pemukiman dan industri. Sungai Banjir Kanal Timur memiliki panjang 14,25 km dengan debit rata-rata 295,33 liter / detik (Bapedalda,2010). Banyak aktivitas manusia dan industri di sekitar daerah aliran sungai (DAS) ini. antara lain adalah industri tekstil,bahan makanan, bahkan terdapat tempat pelelangan ikan. Banyaknya aktiviitas manusia di sekitar wilayah sungai ini menimbulkan berbagai permasalahan lingkungan seperti penurunan kualitas air dan peningkatan proses sedimentasi pada mulut muara merupakan permasalahan yang ditimbulkan (Bapedalda, 2010). Proses sedimentasi yang terjadi secara terus-menerus akan menyebabkan pendangkalan yang berpengaruh terhadap penurunan kapasitas pengaliran sungai. Partikel sedimen yang terbawa oleh aliran sungai menuju ke laut akan 
menyebabkan pengendapan di daerah muara sehingga akan menghalangi aliran sungai ke laut. Maka dari itu dilakukan studi sebaran sedimen di Perairan Banjir Kanal Timur.

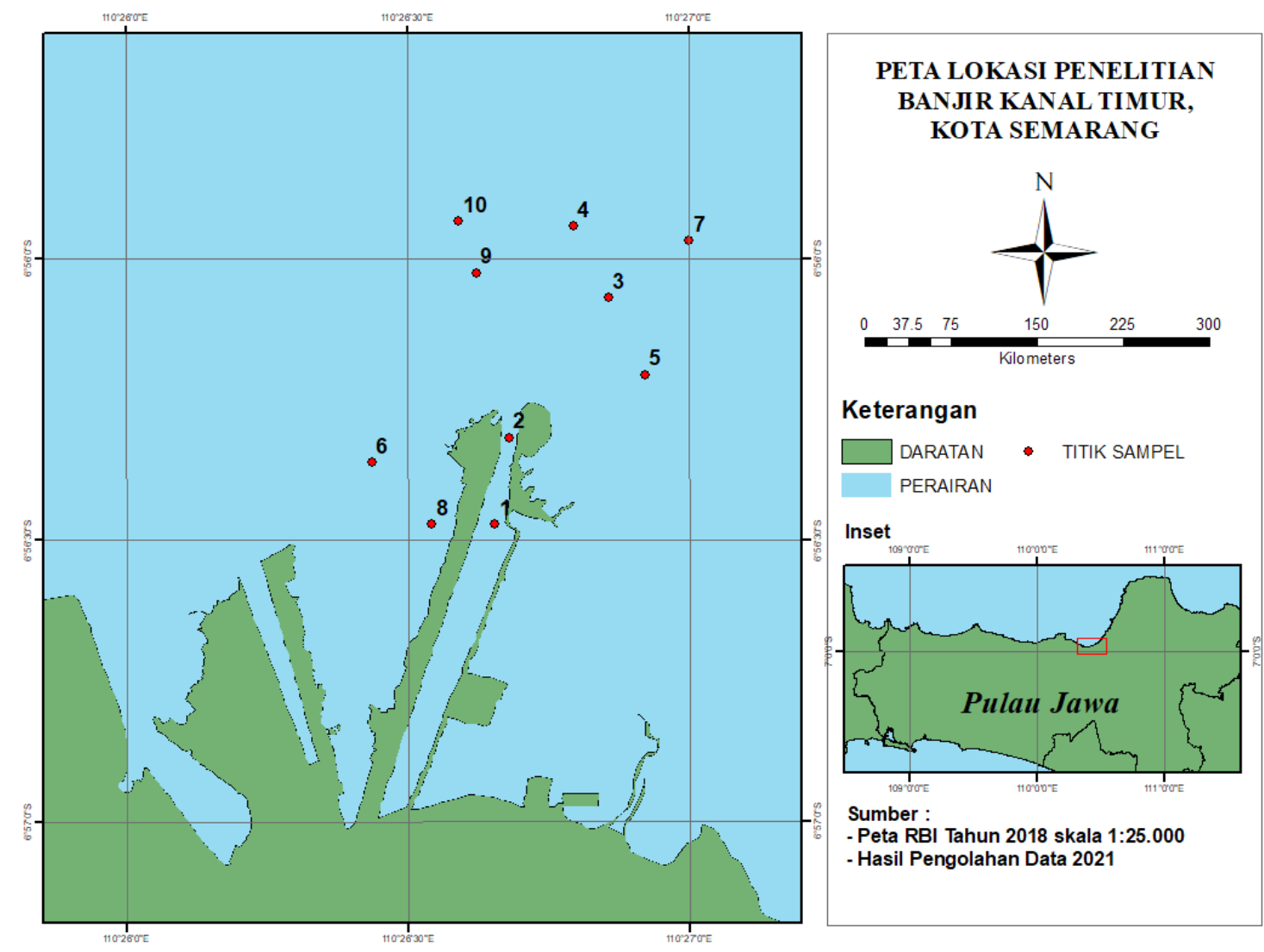

Gambar 1. Peta Lokasi Penelitian

(Sumber : Hasil Pengolahan Data, 2021)

\section{MATERI DAN METODE}

Pengambilan sedimen dasar di Perairan Banjir Kanal Timur diambil pada tanggal 23 Februari 2021 dimana pada bulan itu termsuk Musim Peralihan I. Selain data sedimen dasar, pada 10 stasiun diambil data batimetri lapangan yang nantinya akan dikoreksi dengan data batimetri sekunder dari BATNAS. Pengolahan data sedimen di 10 stasiun untuk mendapatkan jenis sedimen pada setiap stasiun.

Pengolahan data pasang surut sebagai data sekunder dilakukan untuk mengetahui kondisi muka air laut juga menjadi koreksi untuk batimeteri. Data pasang surut secara realtime didapatkan dari http://inasealevelmonitoring.big.go.id/ipasut/ dalam kurun waktu satu bulan. Lalu diolah menggunakan metode Admiralty untuk mendapatkan komponen harmonik pasang surut dan jenis pasang surut di wilayah tersebut.

a. MSL

Muka air laut rata-rata atau lebih dikenal dengan Mean Sea Level (MSL) adalah rata rata nilai tinggi muka air laut selama pengamatan. Nilai tinggi muka air laut pada setiap titik pengukuran selama pengamatan dihitung untuk dicari nilai rata-rata pengukurannya.

\section{b. LLWL}

$$
\mathrm{MSL}=\mathrm{Z} 0+1,1(\mathrm{M} 2+\mathrm{S} 2)
$$

Muka air laut terendah adalah air terendah pada saat pasang surut purnama atau bulan mati air terendah dari dua air rendah dalam satu hari

$$
\mathrm{LLWL}=\mathrm{Z} 0-(\mathrm{M} 2+\mathrm{S} 2)+\mathrm{O} 1+\mathrm{K} 1)
$$




\section{c. HHWL}

Muka air laut tertinggi adalah air tertinggi pada saaat pasang surut purnama atau bulan mati ataupun air tertinggidari dua air tinggi dalam satu hari, seperti dalam pasang surut tipe campuran.

$$
\mathrm{HHWL}=\mathrm{Z0}+(\mathrm{M} 2+\mathrm{S} 2)+(\mathrm{O} 1+\mathrm{K} 1)
$$

dimana :

$\mathrm{Z} 0=\mathrm{S} 0-1,1(\mathrm{M} 2+\mathrm{S} 2+\mathrm{K} 2)$

$\mathrm{O} 1$ = unsur pasut tunggal utama yang disebabkan oleh gaya tarik bulan

$\mathrm{K} 1$ = unsur pasut tunggal yang disebabkan oleh gaya tarik matahari

M2 = unsur pasut ganda utama yang disebabkan oleh gaya tarik bulan

$\mathrm{S} 2$ = unsur pasut ganda utama yang disebabkan oleh gaya tarik matahari

Pola arus didapatkan dari hasil pemodelan MIKE 21 dengan modul Flow Model di 4 kondisi yaitu saat pasang tertinggi, saat surut terendah, saat pasang menuju surut, dan saat susut menuju pasang. Pemodelan arus dilakukan selama 1 bulan yaitu di bulan Februari. Berdasarkan hal ini, pola arus di Perairan Banjir Kanal Timur didominasi oleh arus pasang surut.

\section{HASIL DAN PEMBAHASAN}

Hasil pengolahan data sedimen dasar perairan Banjir Kanal Timur di Laboratorium Geologi FPIK Undip didapatkan ukuran butir sedimen di 10 stasiun. Berdasarkan analisa Segitiga Shepard, didapatkan jenis sedimen pada tiap stasiun yang disajikan pada Tabel 1. Pada tabel tersebut menunjukkan bahwa pada tiap stasiun memiliki kandungan sedimen yang tersusun dari sand, silt dan clay. Diketahui pada peraiaran yang menjauhi pantai umumnya memiliki ukuran butir relatif kasar (Bachtiar, 2002).

Tabel 1. Kandungan Sedimen Perairan Banjir Kanal Timur

\begin{tabular}{ccccccc}
\hline $\begin{array}{c}\text { Titik } \\
\text { Stasiun }\end{array}$ & Bujur Timur & $\begin{array}{c}\text { Lintang } \\
\text { Selatan }\end{array}$ & $\begin{array}{c}\text { Kedalaman } \\
\text { Lapangan } \\
(\mathbf{m})\end{array}$ & $\begin{array}{c}\text { Sand } \\
(\%)\end{array}$ & $\begin{array}{c}\text { Silt } \\
(\%)\end{array}$ & $\begin{array}{c}\text { Clay } \\
(\%)\end{array}$ \\
\hline 1 & $110^{\circ} 26^{\prime} 39.194^{\prime \prime}$ & $6^{\circ} 56^{\prime} 28.394^{\prime \prime}$ & 0,78 & 0 & 991416 & 0,8584 \\
\hline 2 & $110^{\circ} 26^{\prime} 36.686^{\prime \prime}$ & $6^{\circ} 56^{\prime} 27.089^{\prime \prime}$ & 0,64 & 0 & 98,6755 & 1,3245 \\
\hline 3 & $110^{\circ} 26^{\prime} 40.313^{\prime \prime}$ & $6^{\circ} 56^{\prime} 19.310^{\prime \prime}$ & 2,42 & 94,0467 & 5,8193 & 0,1341 \\
\hline 4 & $110^{\circ} 26^{\prime} 55.311^{\prime \prime}$ & $6^{\circ} 56^{\prime} 12.489^{\prime \prime}$ & 3,81 & 98,0009 & 1,9602 & 0,0309 \\
\hline 5 & $110^{\circ} 26^{\prime} 26.697^{\prime \prime}$ & $6^{\circ} 56^{\prime} 21.966^{\prime \prime}$ & 1,67 & 96,4122 & 3,5512 & 0,0366 \\
\hline 6 & $110^{\circ} 26^{\prime} 3.985^{\prime \prime}$ & $6^{\circ} 56^{\prime} 51.508^{\prime \prime}$ & 1,74 & 96,9806 & 2,9715 & 0,0479 \\
\hline 7 & $110^{\circ} 26^{\prime} 37.401^{\prime \prime}$ & $6^{\circ} 56^{\prime} 1.396^{\prime \prime}$ & 3,73 & 95,9752 & 3,9835 & 0,0413 \\
\hline 8 & $110^{\circ} 27^{\prime} 0.085^{\prime \prime}$ & $6^{\circ} 55^{\prime \prime} 58.199^{\prime \prime}$ & 1,14 & 96,8483 & 3,11 & 0,0417 \\
\hline 10 & $110026^{\prime} 47.704^{\prime \prime}$ & $6^{\circ} 55^{\prime \prime} 56.589^{\prime \prime}$ & 3,13 & 95,8462 & 4,1319 & 0,022 \\
\hline $110^{\circ} 26^{\prime} 35.484^{\prime \prime}$ & $6^{\circ} 55^{\prime \prime} 56.086^{\prime \prime}$ & 4,08 & 98,5105 & 1,3883 & 0,1012 \\
\hline
\end{tabular}

Hasil analisa sampel sedimen tersebut dibuat peta sebaran jenis sedimen pada Gambar 2 yang diolah menggunakan software Arc Gis 10.3 untuk mengetahui sebaran jenis sedimen di perairan Banjir Kanal Timur. 

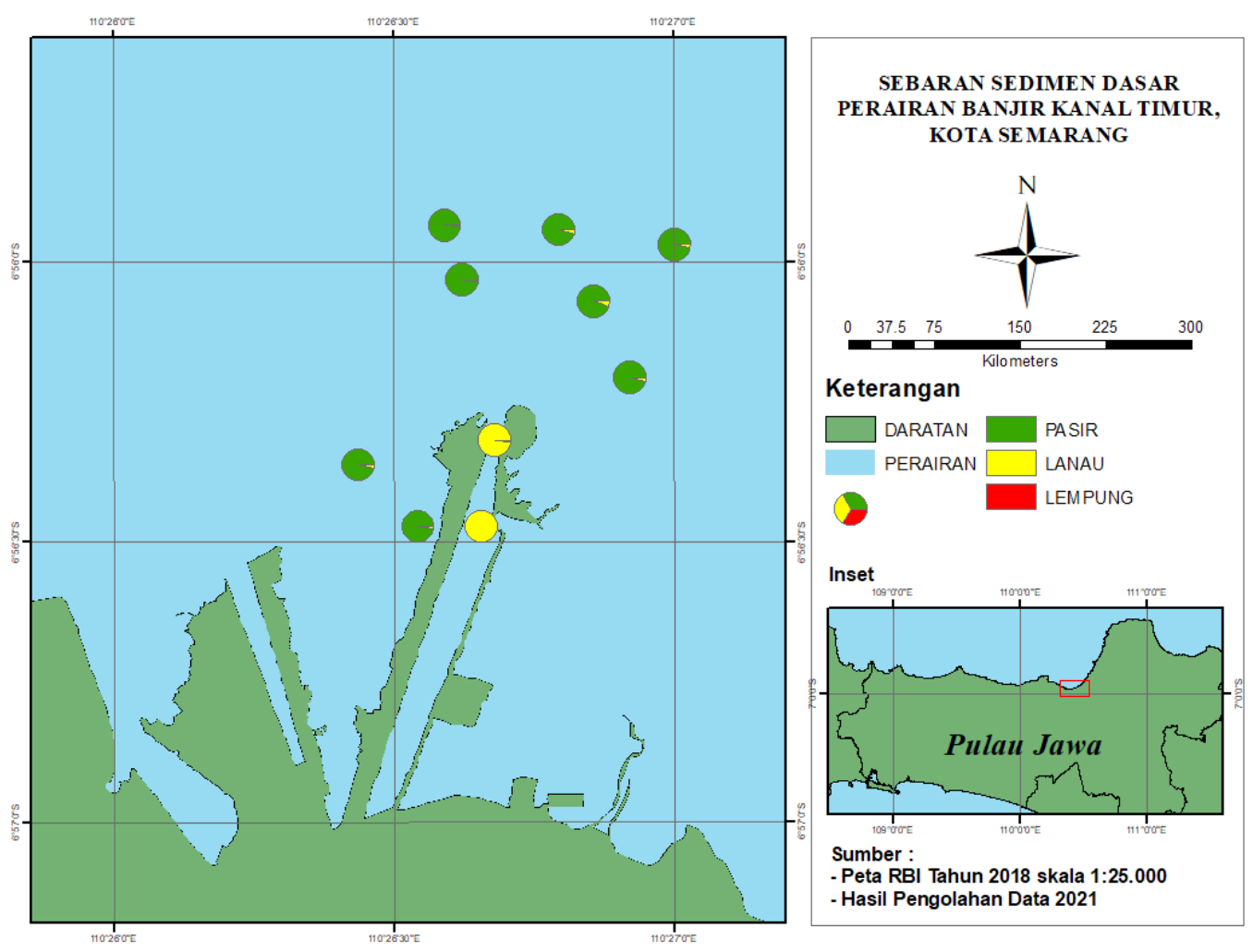

Gambar 2. Peta Sebaran Jenis Sedimen di Perairan Banjir Kanal Timur

Hasil pengolahan data pasang surut sebagai data sekunder didapatkan nilai pasang surut dengan elevasi tertinggi sebesar $241 \mathrm{~cm}$ dan nilai elevasi terendah $162 \mathrm{~cm}$. Pengolahan data pasang surut untuk mendapatkan nilai komponen pasang surut menggunakan metode Admiralty dari hasil pengukuran pasut selama 30 hari disajikan pada Tabel 2.

Tabel 2. Komponen Pasang Surut Perairan Semarang

\begin{tabular}{ccccccccccc}
\hline & $\mathrm{S}_{0}$ & $\mathrm{M}_{2}$ & $\mathrm{~S}_{2}$ & $\mathrm{~N}_{2}$ & $\mathrm{~K}_{1}$ & $\mathrm{O}_{1}$ & $\mathrm{M}_{4}$ & $\mathrm{MS}_{4}$ & $\mathrm{~K}_{2}$ & $\mathrm{P}_{1}$ \\
\hline $\mathrm{A} \mathrm{Cm}$ & 188.3 & 12,27 & 6,179 & 3,994 & 10,38 & 4,957 & 5,665 & 7,889 & 1,668 & 3,424 \\
\hline $\mathrm{g}^{\circ}$ & 0 & 55,45 & 86,5 & 57,82 & 411,73 & 154,8 & 20,5 & 79,17 & 23,36 & 135,9 \\
\hline
\end{tabular}

Hasil komponen pasang surut di Perairan Semarang digunakan untuk menghitung nilai Formzhal dan kedudukan muka air laut. Nilai Formzhal untuk daerah Perairan Semarang menunjukkan nilai 0,81329 yang merupakan tipe pasang surut condong ke harian ganda. Tipe pasang surut condong harian ganda merupakan tipe pasang surut yang terjadi dua kali pasang dan dua kali surut dalam waktu satu hari. Hal ini selaras dengan penelitian Rachman et al (2015) yang menyatakan bahwa hasil analisis menggunakan metode Admiralty didapatkan nilai Formzhal Perairan Semarang sebesar 1,121 sehingga tipe pasang surut di Perairan Semarang diklasifikasikan dalam tipe pasang susurt condong ke harian ganda dengan nilai Formzhal diantara $0,25<\mathrm{F}<$ 1,5. Kedudukan muka air laut di Perairan Semarang juga dapat dilihat pada Tabel 3. 
Tabel 3. Nilai Komponen Harmonik Pasang Surut (cm)

\begin{tabular}{ccccccc}
\hline F & MSL & Z $_{\mathbf{0}}$ & HHWL & MHWL & LLWL & MLWL \\
\hline 0,83129 & 188,263 & 56,4175 & 244,68 & 74,8621 & 144,111 & 33,9786
\end{tabular}

Berdasarkan data pasang surut daerah Perairan Semarang pada bulan Februari 2021 dibuat grafik yang dapat dilihat juga tipe pasang surutnya. Berikut grafik pengamatan pasang surut selama satu bulan yang merupakan tipe condong harian ganda pada Gambar 3.

\section{Grafik Pasang Surut Februari 2021 Perairan Semarang}

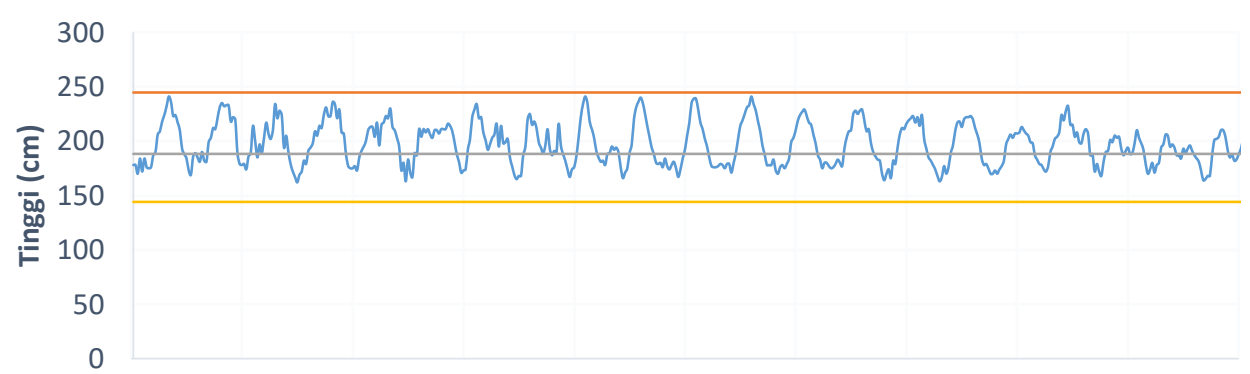

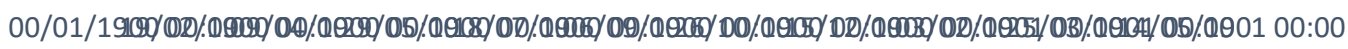
Waktu Elevasi $\longrightarrow$ HHWL $\longrightarrow$ MSL LLWL

Gambar 3. Grafik Pasang Surut Bulan Februari 2021 di Perairan Semarang

Berdasarkan hasil pengukuran kedalaman di lokasi penelitian setelah dikoreksi dengan faktor pasang surut dan kedalaman BATNAS, maka didapatkan kedalaman terendah di stasiun 1 dan 2 yang berada di tepi mulut Muara Sungai Banjir Kanal Timur sebesar 0,789 m dan 0,723m. Kedalaman tertinggi berada di stasiun 9 yang berada cukup jauh dari Muara Sungai Banjir Kanal Timur.

Tabel 4. Batimetri Perairan Banjir Kanal Timur

\begin{tabular}{ccccc}
\hline Bujur Timur & Lintang Selatan & $\begin{array}{c}\text { Kedalaman } \\
\text { Lapangan }(\mathbf{m})\end{array}$ & $\begin{array}{c}\text { Kedalaman } \\
\text { Terkoreksi(m) }\end{array}$ & $\begin{array}{c}\text { Kedalaman } \\
\text { Sekunder }(\mathbf{m})\end{array}$ \\
\hline $110^{\circ} 26^{\prime} 39.194^{\prime \prime}$ & $6^{\circ} 56^{\prime} 28.394^{\prime \prime}$ & 0,78 & 0,88 & 0,789 \\
\hline $110^{\circ} 26^{\prime} 36.686^{\prime \prime}$ & $6^{\circ} 56^{\prime} 27.089^{\prime \prime}$ & 0,64 & 0,97 & 0,723 \\
\hline $110^{\circ} 26^{\prime} 40.313^{\prime \prime}$ & $6^{\circ} 56^{\prime} 19.310^{\prime \prime}$ & 0,91 & 1,5 & 1,137 \\
\hline $110^{\circ} 26^{\prime} 55.311^{\prime \prime}$ & $6^{\circ} 56^{\prime} 12.489^{\prime \prime}$ & 1,37 & 1,85 & 1,421 \\
\hline $110^{\circ} 26^{\prime} 26.697^{\prime \prime}$ & $6^{\circ} 56^{\prime} 21.966^{\prime \prime}$ & 1,6 & 1,74 & 1,875 \\
\hline $110^{\circ} 26^{\prime} 3.985^{\prime \prime}$ & $6^{\circ} 56^{\prime} 51.508^{\prime \prime}$ & 1,74 & 2,14 & 2,328 \\
\hline $110^{\circ} 26^{\prime} 37.401^{\prime \prime}$ & $6^{\circ} 56^{\prime} 1.396^{\prime \prime}$ & 2,03 & 2,56 & 2,675 \\
\hline $110^{\circ} 27^{\prime} 0.085^{\prime \prime}$ & $6^{\circ} 55^{\prime \prime} 58.199^{\prime \prime}$ & 2,55 & 3,21 & 3,12 \\
\hline $110 \mathrm{o} 26^{\prime} 47.704^{\prime \prime}$ & $6^{\circ} 55^{\prime \prime} 56.589^{\prime \prime}$ & 3,13 & 3,79 & 3,76 \\
\hline $110^{\circ} 26^{\prime} 35.484^{\prime \prime}$ & $6^{\circ} 55^{\prime \prime} 56.086^{\prime \prime}$ & 2,6 & 3,27 & 2,965 \\
\hline
\end{tabular}


Peta batimetri dapat dilihat pada Gambar 4. Tampilan peta menggunakan interval kontur yang kecil supaya terlihat jelas dan mencakup seluruh area penelitian. Pada daerah sungai, kontur terlihat mengikuti bentuk sungai. Pada bagian laut lepas, kontur terlihat sejajar dengan tepi daratan sungai dan memiliki jark yang tetap satu sama lain. Kontur yang memiliki jarak yang tetaap menggambarakan bahwa kedalaman Perairan Banjir Kanal Timur memiliki kemiringan yang teraratur.
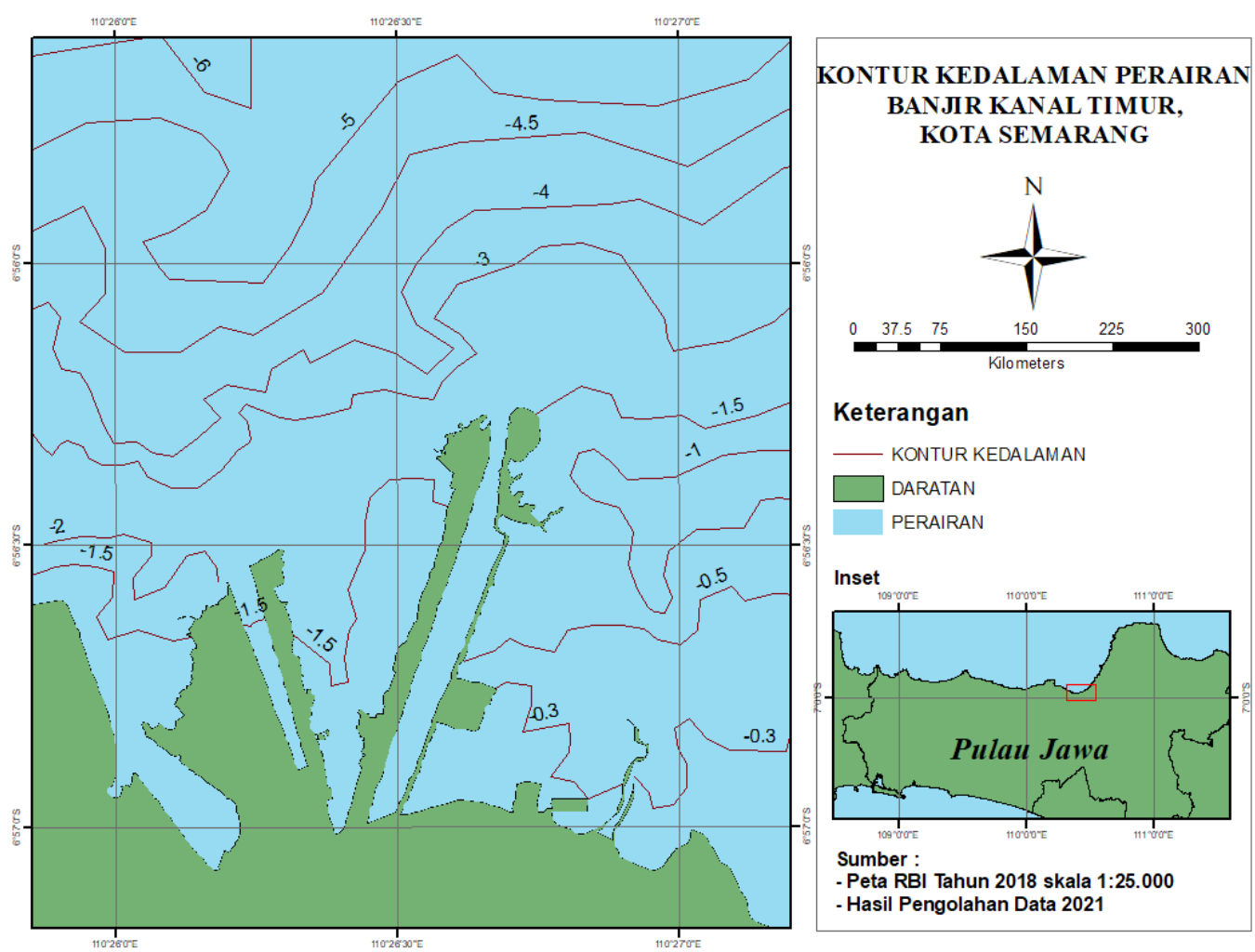

Gambar 4. Peta Batimetri Perairan Banjir Kanal Timur

Pemodelan pola arus menggunakan software MIKE 21 untuk mendapatkan pola arus di Perairan Banjir Kanal Timur, Semarang. Simulasi pemodelan dilaksanakan selama 1 bulan yaitu bulan Februari 2021. Hasil pemodelan arus berupa vektor arah arus agar mempermudah analisa pengaruh arus terhadap sebaran sedimen di Perairan Banjir Kanal Timur. Hasil simulasi arus terbagi menjadi 4 kondisi yaitu pola arus saat pasang tertinggi, saat pasang menuju surut, saat surut terendah dan saat surut menuju pasang.

Kecepatan arus maksimum pada saat pasang tertinggi dan saat surut menuju pasang secara berurutan sebesar $0,181372 \mathrm{~m} / \mathrm{s}$ dan $0,179726 \mathrm{~m} / \mathrm{s}$. Hasil arus pada saat pasang tertinggi menunjukkan vektor cenderung ke arah tenggara sedangkan pada saat surut menuju pasang dominan ke 2 arah yaitu selatan dan barat daya yang dua-duanya mendekati wilayah daratan. Kecepatan arus maksimum pada saat surut terendah dan saat pasang menuju surut secara berurutan sebesar $0,18067 \mathrm{~m} / \mathrm{s}$ dan $0,215069 \mathrm{~m} / \mathrm{s}$. Hasil arus pada saat surut terendah dan pada saat pasang menuju surut dominan ke arah barat laut dimana menjauhi wilayah daratan. 

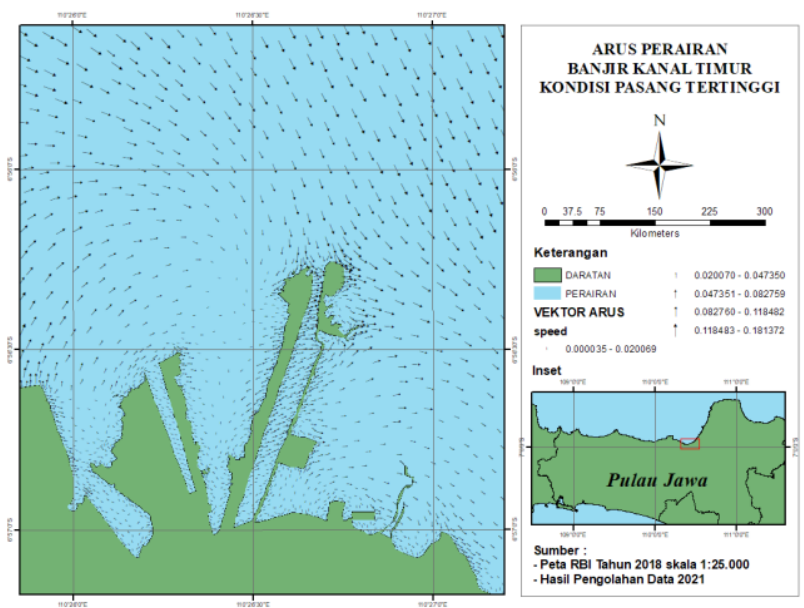

Gambar 5a. Arus Perairan Banjir Kanal Timur saat Pasang tertinggi
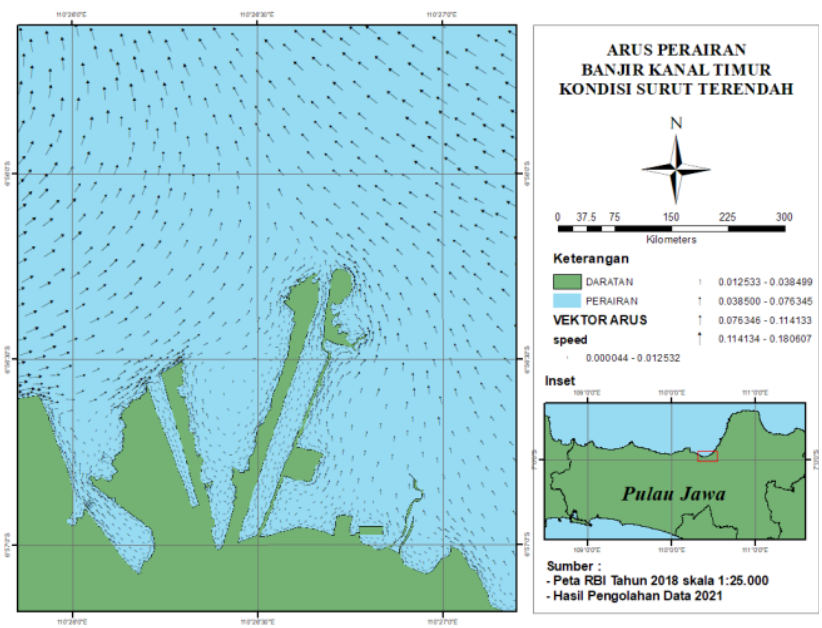

Gambar 5c. Arus Perairan Banjir Kanal Timur saat Surut Terendah
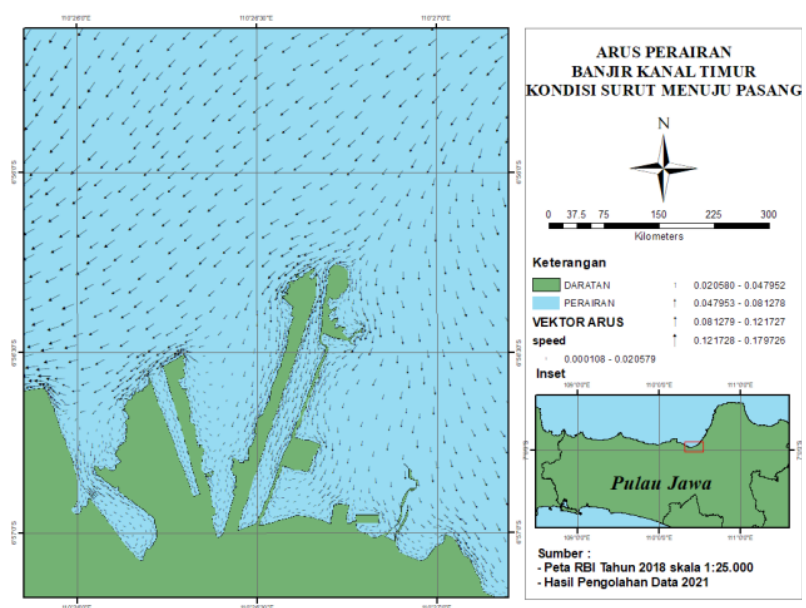

Gambar 5b. Arus Perairan Banjir Kanal Timur saat Surut menuju Pasang
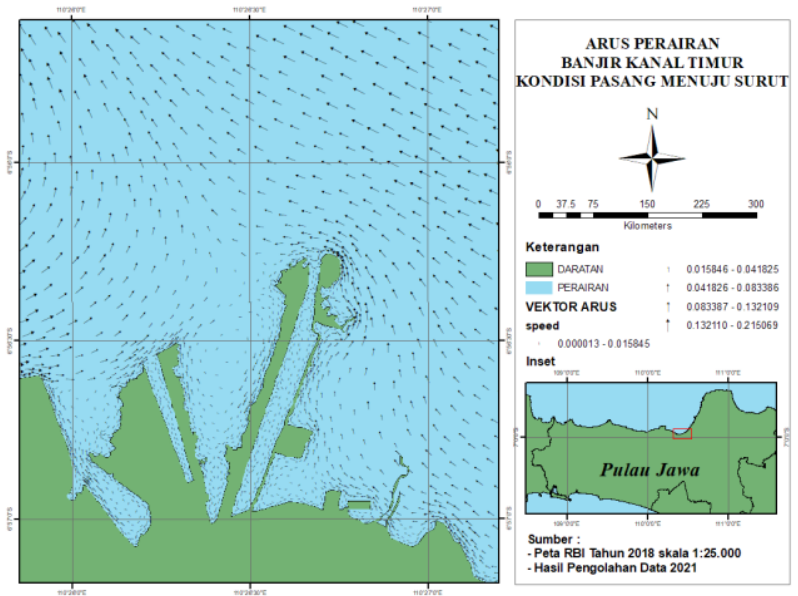

Gambar 5d. Arus Perairan Banjir Kanal Timur saat Pasang menuju Surut

Gambar 5a-d. a (arus saat pasang tertinggi); b (arus saat surut menuju pasang); c (arus saat surut terendah); dan d (arus saat pasang menuju surut)

Hasil pengolahan data terhadap kandungan dan sebaran sedimen menujukkan pada daerah Perairan Banjir Kanal Timur dominan pasir 94-98 \% yang terdapat di stasiun 3 sampai 10. Selanjutnya kandungan silt dengan nilai ang cukup tinggi sebesar 98-99\% ada pada stasiun 1 dan 2. Dapat dilihat berdasarkan peta lokasi titik stasiun menunjukkan stasiun 1 dan 2 berada di muara sungai Banjir Kanal Timur, dan stasiun selanjutnya sudah memasuki wilayah Laut Jawa. Berdasarkan data kandungan sedimen pada Tabel 5, bahwa kandungan sand di stasiun 3 hingga stasiun 10 mengalami peningkatan, hal ini disebabkan karena stasiun 3 hingga 10 menyebar di daerah Laut Jawa dan cukup jauh dari wilayah daratan. Sedangkan di stasiun 1 dan 2 yang masih berada di muara Sungai Banjir Kanal Timur memiliki kandungan silt yang besar, dan tidak memiliki kandungan sand sama sekali. Namun pada setiap stasiun memiliki kandungan clay dengan rentang yang sangat kecil yaitu $0,022 \%$ hingga $1,3245 \%$ saja. Hal ini selaras dengan penelitian Victoria et al (2018) yang menyatakan bahwa komponen sedimen di daerah Sungai Banjir Kanal Timur yang mengalir dan terlarut dalam aliran sungai sebagaian besarnya adalah lanau kelempungan. Sungai Banjir Kanal Timur juga memiliki debit aliran rata- rata sebesar 79,0025 m³ $/ \mathrm{s}$ dengan kecepatan aliran sungai $0,25 \mathrm{~m} / \mathrm{s}$. Muara sungai Banjir Kanal Timur adalah tipe muara yang didominasi oleh aliran sungai atau biasa disebut tide dominated river mouth. Kecepatan aliran yang rendah di hilir sungai berdampak pada gerakan sedimen ke arah laut yang lambat 
sehingga menimbulkan sedimentasi di daerah sungai. Penelitian ini dilakukan pada bulan Februari dimana bulan tersebut masih termasuk dalam musim penghujan, hal ini menyebabkan masukan sedimen dari muara sungai sangat berpengaruh. Sedimen yang dibawa oleh aliran sungai akan mengendap di daerah muara sungai. Menurut Triatmodjo (1999), masukan sedimen (suplai) dan yang meninggalkan pantai mempengaruhi suatu pantai untuk mengalami erosi, sedimentasi atau tetap stabil.

Pemodelan arus menggunakan modul hidrodinamika MIKE 21 Flow Model menunjukkan pola pergerakan arus di Sungai Banjir Kanal Barat mengikuti pola pasang surut di daerah penelitian. Sehingga pemodelan data arus di daerah penelitian ini didominasi oleh arus pasang surut. Hasil pemodelan arus disajikan dalam 4 kondisi yaitu saat pasang tertinggi, saat surut terendah, saat pasang menuju surut dan saat surut menuju pasang. Pada saat kondisi pasang dan surut menuju pasang, vektor arus bergerak mendekati daratan. Sebaliknya, saat surut dan pasang menuju surut, vektor arus bergerak menjauhi daratan menuju ke laut lepas. Hal tersebut disebabkan pada saat pasang dan surut menuju pasang, muka air laut mengalami kenaikan dan mendekati wilayah daratan sehingga pola arus ditunjukkan bergerak dari laut menuju darat. Sedangkan pada saat surut dan pasang menuju surut, muka air laut mengalami penurunan sehingga air laut akan bergerak menjauhi daratan sehingga pola arus ditunjukkan bergerak dari daratan menuju laut lepas yang ditunjukkan Gambar 5(a-d) Menurut Brown (1989), pada saat surut terendah dan pasang tertinggi maka terjadi pasang surut minimum, berbeda dengan kondisi pada saat trasnsisi surut menuju pasang dan pasang menuju surut terjadi pasut maksimum. Hal ini terjadi akibat saat kondisi pasang dan surut, arus cenderung diam dan akan bergerak ketika terdapat perubahan tinggi muka air, sehingga kecepatan arus lebih tinggi saat transisi pasang menuju surut maupun surut menuju pasang.

Penelitian ini menunjukkan bahwa sedimen dasar pada Muara Banjir Kanal Timur didomiasi oleh lanau, semakin menuju laut lepas didominasi oleh pasir. Persebaran sedimen di Muara Banjir Kanal Timur disebabkan oleh suplai sedimen dari Sungai Banjir Kanal Timur yang membantu membawa sedimen dari hilir ke hulu. Sedangkan pada perairan yang lebih dalam, akibat kecepatan arus yang tidak terlalu besar mengakibatkan suplai dari daerah muara lebih besar daripada masukan dari laut lepas. Sedimen jenis lanau memiliki sifat kohesif dimana sulit terdistribusi oleh arus. Sungai Banjir Kanal Timur di daerah penelitian membawa material sedimen, hal ini memungkinkan terjadinya pnegendapan di sekitar Muara Banjir Kanal Timur akibat pengaruh arus dan debit sungai. Akumulasi sedimen yang masuk (suplai) dan sedimen yang meninggalkan pantai mempengaruhi luas daratan di daerah pesisir.

\section{KESIMPULAN}

Sebaran jenis sedimen pada perairan Banjir Kanal Timur yaitu pasir dan lanau. Pada daerah dekat muara Sungai Banjir Kanal Timur mengandung jenis sedimen lanau, sedangkan pada daerah yang lebih dalam (laut lepas) mengandung jenis sedimen pasir.Pola arus pada perairan Banjir Kanal Timur memiliki pola arus pasang surut, dimana hasil pemodelan dalam 4 kondisi menunjukkan kecepatan arus lebih kecil pada saat pasang tertinggi maupun surut terendah dibandingan dengan kondisi pada saat transisi pasang ke surut maupun surut ke rendah.

\section{DAFTAR PUSTAKA}

Bachtiar, T. 2006. Tracing Sewage Contamination in Urban Tropical Coastal Waters. Ilmu Kelautan: Indonesian Journal of Marine Sciences, 11(4) : 221-226.

Brown, J. (1989). Waves, Tides and Shallow Water Processced.

Buchanan, J. B. 1984. Sediment Analysis and Suspended Particulated Matter, Fisheries and Marine Service Technical Report No. 700, Environmental. Canada.

Djunarsjah, E., dan Poerbandono, 2005, Survei Hidrografi. PT. Refika Aditama, Bandung.

Duxbury, A.C., and Alison, B. Duxbury., 1991. An introductio to the Wolrd's Oceans 3rd Edition. Wm C Brown. Dubuque. 
Engelund, F., \& Hansen, E. 1967. A Monograph on Sediment Transport in Alluvial Streams. Technical University of Denmark 0stervoldgade 10, Copenhagen K.Friedman, G.M., \& Sanders, J.E., 1978, Principles of Sedimentology, John Wiley \& Sons, New York, Chichester, Brisbane, Toronto, Singapore.

Gross, M., Grant., 1993. Oceanography a View of Earth. 6th Edition. Prentice-Hall. New Jersey. 191 pp. Gross,M.G. 1990. Oceanography : A View Of Earth. Patience Hall, Inc. Englewood Cliff. New Jersey, 57 p. Hariadi, et al. 2015. Sebaran Sedimen Dasar di Muara Sungai Pekalongan.Jurnal Kelautan.

Merchant, Kenneth.A., (1982). "The Control Function of Management". Sloan Management Review 24: 43 55.

Rachman R.K, Ismunarti D.W, Handoyo. 2015. Pengaruh Pasang Surut Terhadap Sebaran Genangan Banjir Rob di Kecamatan Semarang Utara. Jurnal Oseanografi. 4 (1) : 1-9.

Triatmodjo, B. 1999. Teknik Pantai. Beta Offset : Yogyakarta

Victoria, C.E, Bernike I., Salamun, Sugiyanto. (2018). Perencanaan Perbaikan Muara Sungai Banjir Kanal Timur Semarang. Jurnal Karya Teknik Sipil. 7 (1) : 189- 209 